DEMI (MOSHO) Albana, KADIU Arjana

\title{
ALBANIA AND CULTURAL SOCIAL ECONOMIC DEVELOPMENT
}

In Happiness And Contemporary Society : Conference Proceedings Volume (Lviv, March, 20-21, 2021). Lviv: SPOLOM, 2021. P. 82-85. https://doi.org/10.31108/7.2021.16

ISBN 978-966-919-697-2 


\title{
DEMI (MOSHO) Albana
}

Doctor, Lecturer and Researcher, University “Aleksandër Moisiu” (Durrës, Albania)

\author{
KADIU Arjana \\ PhD, Lecturer and Researcher, University “Aleksandër Moisiu” (Durrës, Albania)
}

\section{ALBANIA AND CULTURAL SOCIAL ECONOMIC DEVELOPMENT}

Everyone This paper aims to present the social and cultural side in Albania, intertwined with the economic aspect, based on the analysis of the changes occurred recently in our country. Considering the happiness as a key daily factor this paper will give an overview of the public policies, including public and family costs.

The purpose of this paper is to analyze if the welfare is provided only in conditions of an environment characterized by the economic, political and social stability.

The research is based on the data collected by the public institutions regarding the social policies, economic growth, challenges of tourism, as well as the different cultures that exist in Albania. growth.

Keywords: public policies, economic, social policies, tourism, culture, economic

Introduction

Currently, the whole world is facing great challenges, therefore, today more than ever there is a need for new generations who will be ready to lead and advance economic processes and social policies. In general in the analytical framework, the basic knowledge and approaches for proper further study and development for each of the science disciplines and especially the studies on public happiness analysis are factors that influence the consolidation, and development of policy-making and governance. As we are surrounded by public policies, achieving social well-being is significant for analyzing dynamic processes. Culture plays an important role in the use of social media, liberal countries, compared to countries where freedom of speech is restricted, have a higher number of users and express more positive attitudes towards them.

Alsaleh, Elliott, Fu \& Thakur (2019) aimed to explore how culture can help predict people's attitude towards Instagram. The higher the trust in this site the higher the perceived usefulness and the higher the number of Instagram users.

\section{Methodology}

The purpose of this paper is to provide a summary overview of the relationship between socio-economic development and happiness for contemporary societies.

The question posed in this paper is: Is happiness involved in public policy making?

To answer the question in this study, were reviewed, the literature of public institutions in Albania as well as data on the tourism development strategy as one of the key points in the Albanian economy.

Andrew Steptoe (2019) - In his research results on happiness and health he has been dominated by observational epidemiological studies, according to which the meaning between happiness and health includes the integration of epidemiological research with clinical and experimental work. Ada Ferrer-i-Carbonell (2012) on her research study concluded that happiness Economics has experienced an important growth is very recent years. 
According to David Blanchflower for the some individuals, a doubling salary makes a lot less difference than life events like marriage or unemployment.

Results and discussions

Different studies is noticed that there is no specific empirical finding to determine the impact of happiness on health costs but taking into account the global trend is often aimed at using social media to achieve customer satisfaction and brand distribution in the population wide. Good samples in this field are also Erdoğmuş \& Cicek (2012) who identified the key factors that help maintain brand loyalty in the customer base.

Albania in terms of positioning is a country with a golden necklace, with rich health values, with an impressive culture in hospitality. Tourism is an economic activity or a set of activities closely coordinated with each other that aim to meet the needs of individuals, related to leisure and movement of people.

Today in Albania, tourism represents an industry, because it is about activities that aim at the use of tourist resources, as well as the transformation of natural, human and capital resources into tourism products and services. Albania has the potential to develop coastal tourism, mountain tourism, etc. making it possible to calculate its real impact on the country's GDP and has a wide range of historical, cultural and natural attractions that constitute a major interest for international tourists. Albania is traversed by a $362 \mathrm{~km}$ long coastline and has inherited 2000 objects declared cultural monuments, three of which are world heritage of humanity protected by UNESCO (Butrint, Berat and Gjirokastra). In this aspect, Albania is unique in its kind and offers a very wide range of investment opportunities in the field of tourism.

Focusing on the happiness that any individual finds by getting involved in the cultural and literary activities, this paper will bring below, for the period 2018-2020 the presentation in table form and in graphic form the total number of shows compared to the number of visitors or spectators, Visitors in Museum, Archaeological Parks, Castle, Attendance and publications in the National Library.

Table:1 Total number of shows comparing with visitors 2018-2020

\begin{tabular}{|c|c|c|c|c|c|c|}
\hline \multirow[b]{2}{*}{ Tot. number of shows/spectators/visit } & \multicolumn{3}{|c|}{ Total number of shows } & \multicolumn{3}{|c|}{ Tot. number of spectators/visitors } \\
\hline & 2018 & 2019 & 2020 & 2018 & 2019 & 2020 \\
\hline National People's Theater & 156 & 157 & 63 & 39503 & 34790 & 5252 \\
\hline The National Experimental Theater & 457 & 444 & 135 & 65989 & 64684 & 16044 \\
\hline $\begin{array}{l}\text { National Theater of Opera, Ballet and } \\
\text { National Ensemble }\end{array}$ & 97 & 161 & 45 & 54438 & 70647 & 7476 \\
\hline National Center for Children's Culture & 198 & 236 & 65 & 22051 & 31795 & 6274 \\
\hline National Circus & 124 & 126 & 20 & 34969 & 21698 & 3286 \\
\hline Tot. number of shows/spectators/visitors & 1,032 & 1124 & 328 & 216950 & 223614 & 38332 \\
\hline
\end{tabular}

Source: Authors' work 
Graphic:1 Total number of shows comparing with visitors 2018-2020

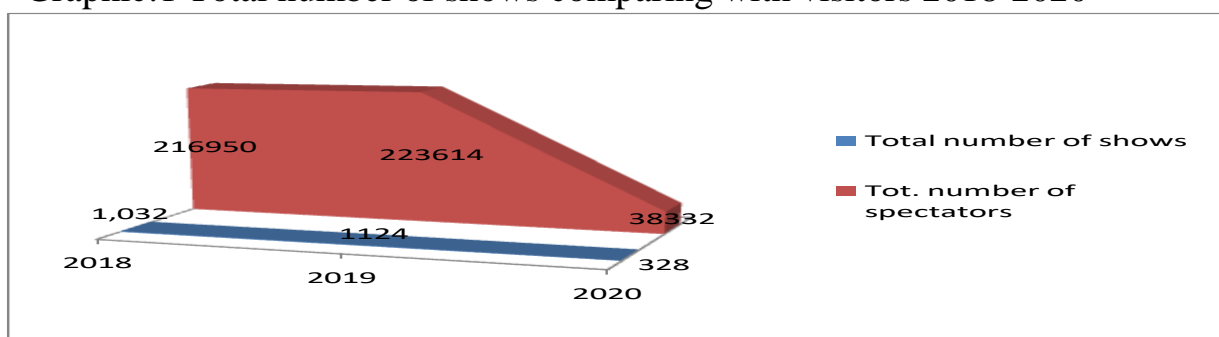

Source: Authors' work

Table:2 Visitors in Museum, Archaeological Parks, Castle and other monuments

\begin{tabular}{|c|c|c|c|c|}
\hline & Museum & $\begin{array}{l}\text { Castle and } \\
\text { other } \\
\text { monuments }\end{array}$ & $\begin{array}{l}\text { Archaeolo } \\
\text { gical Parks }\end{array}$ & $\begin{array}{l}\text { Total number } \\
\text { of visitors }\end{array}$ \\
\hline $\mathbf{2 0 1 8}$ & 311940 & 308656 & 377845 & $\mathbf{9 9 8 4 4 1}$ \\
\hline $\mathbf{2 0 1 9}$ & 317,826 & 322,395 & 424,860 & $\mathbf{1 , 0 6 5 , 0 8 1}$ \\
\hline $\mathbf{2 0 2 0}$ & 49288 & 62627 & 78552 & $\mathbf{1 9 0 4 6 7}$ \\
\hline
\end{tabular}

Source: Authors' work

Graphic:2 Visitors in Museum, Archaeological Parks, Castle and other monuments

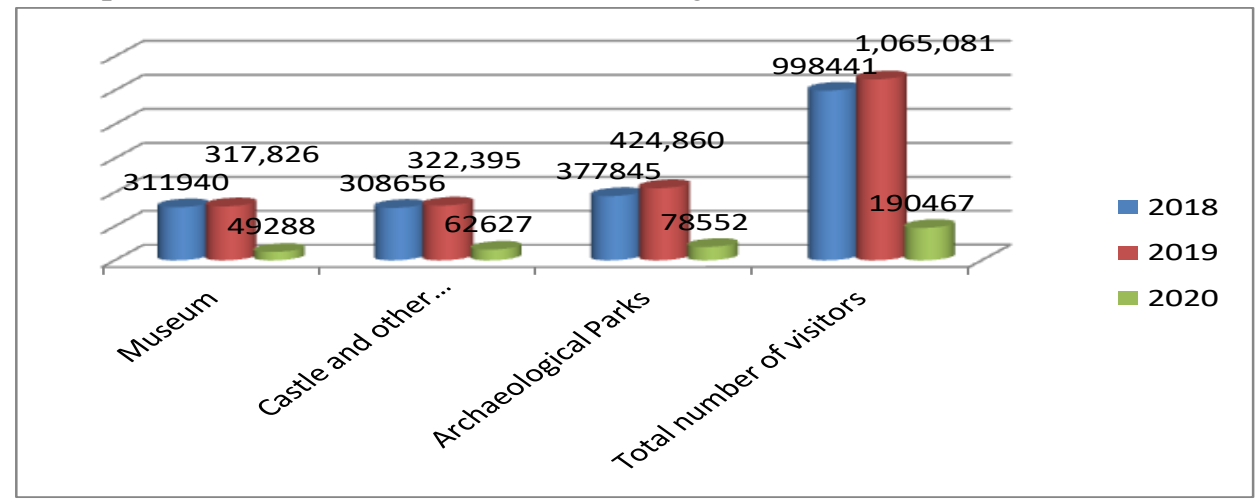

Source: Authors' work

Table:3 Attendance and publications in the National Library

\begin{tabular}{|c|r|r|r|r|}
\hline $\begin{array}{l}\text { Library Unit } \\
\text { Service } \\
\text { (Unit) }\end{array}$ & Attendance & $\begin{array}{l}\text { Culture and } \\
\text { scientific } \\
\text { activities }\end{array}$ & $\begin{array}{l}\text { Number } \\
\text { of new titles } \\
\text { during the } \\
\text { year }\end{array}$ & $\begin{array}{l}\text { Number } \\
\text { of new } \\
\text { exemplars } \\
\text { during the } \\
\text { year }\end{array}$ \\
\hline 89,212 & 82,414 & 269 & 2,895 & 7,136 \\
\hline 99,741 & 132,462 & 149 & 4,075 & 14,933 \\
\hline 20,306 & 30,002 & 95 & 2,537 & 11,022 \\
\hline
\end{tabular}

Source: Authors' work 
Graphic: 3 Attendance and publications in the National Library

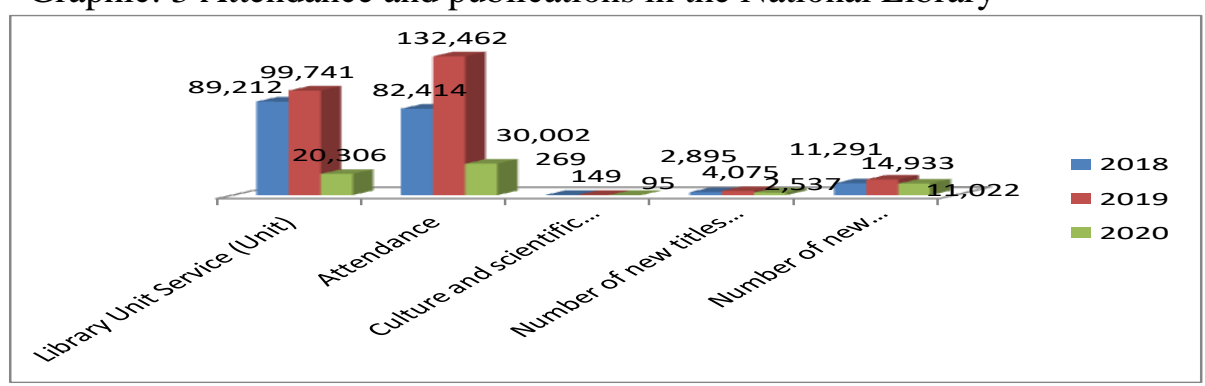

Source: Authors' work

In all the tables or graphs presented above it is observed that the situation of Covid-19 has imposed the participation of individuals in theater, cinema, museum, library, it is also clear that publications in the International Library have a very large decline. So, these public institutions have experienced significant income reduction in 2020 , comparing with previous two years.

Conclusion

To answer the research question of this study, have been analyzed some aspects of happiness that individuals and society go through in daily life. In any time the individual happiness is much related to the cultural life, with health, study, physiology, public economy, household economy, development of technologies, tourism sector, so happiness is related to all the individuals 'daily life. The contemporary philosophy of happiness is the key to success of a healthy family, for a healthy society and for an individual prepared to face the challenges of the time.

Based on this study, we recommend policymakers during the public policy-making process to consider the happiness of individuals, to design social policies that will ensure continuous welfare population growth.

\section{REFERENCES}

1. "Cross-cultural differences in the adoption of social media" - Alsaleh, Elliott, Fu \& Thakur (2019) - https://scholar.google.com Journal of Research in Interactive Marketing ISSN: 2040-7122 / Publication date: 11 March 2019

2. "Happiness economics" Ada Ferrer-i-Carbonell (2012) - https://scholar.google.com/ SERIEs (2013) 4:35-60 DOI 10.1007/s13209-012-0086-7

3. The Impact of Social Media Marketing on Brand Loyalty - Author links open overlay panelİrem ErenErdoğmuşaMesutÇiçekb - https://scholar.google.com - Procedia - Social and Behavioral Sciences/Volume 58, 12 October 2012, Pages 1353-1360

4. Happiness and Health - Andrew Steptoe (2019) - https://scholar.google.com - Annual Review of Public Health" Vol. 40:339-359 (Volume publication date April 2019)

5. What can economists learn from happiness research? - Bruno S Frey, Alois Stutzer https://scholar.google.com -Journal of Economic Literature 2002/6/1, Volume 40, Issue 2, Pages 402-435

6. Happiness Economics - David Blanchflower - ISSUE: No. 2, June 2008 -National Bureau of Economic research. https://scholar.google.com

7. Carol Graham - HEALTH AFFAIRS VOL. 27, NO. 1 : - https://scholar.google.com

8. Easterlin, Richard A.Does Money Buy Happiness? - https://scholar.google.com The Public Interest; New York, Vol. 30, (Winter 1973): 3.

9. Ed Diennr, Shigehiro Oishi, and Richard E Lucas, Subjective well-being the science of Happiness and life satisfaction - The Oxford Handbook of Positive Psychology https://scholar.google.com 